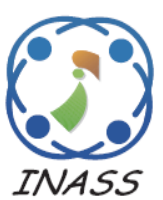

\title{
Measuring Students' Intention to Use E-Learning During Covid-19 Pandemic: A Case Study in Technical College of Management - Baghdad
}

\author{
Mohammed Fadhil Ibrahim ${ }^{1 *}$ \\ Huda Khurshed Shawkat Aljader ${ }^{1}$ \\ ${ }^{1}$ Middle Technical University (MTU), Iraq \\ * Corresponding author's Email: mfi@mtu.edu.iq
}

Nawar Abbood Fadhil ${ }^{1}$

\begin{abstract}
Covid-19 pandemic affected our daily activities. Education is the fastest aspect that has been hindered due to the pandemic. The majority of the schools and universities were prone to global closure. The world turned toward using e-learning as an alternative to traditional learning due to the strict lockdown procedures. This study presents a model to measure the students' intention to use e-learning during the pandemic in Iraq. Technology Acceptance Model (TAM) is utilized with some external variables. Task Technology Fit (TTF) is also adopted as a moderator for the proposed model. The model is implemented on a sample of students studying at Technical College of Management Baghdad who have completed the academic year using e-learning. Eighteen hypotheses were formulated; out of them, only two were rejected. The model is tested and evaluated using PLS Tool. The results showed that the students have a positive intention to use e-learning during the covid-19 pandemic; also, most of the external variables were statistically significant. Furthermore, using TTF positively moderates the proposed model. The results open the way to perform more investigations in adopting e-learning during unusual situations.
\end{abstract}

Keywords: Covid-19, E-learning in iraq, Technology acceptance model (TAM), Task technology fit (TTF).

\section{Introduction}

The first occurrence of (COVID-19) was reported in China, specifically in Wuhan city. The virus fulminated madly to affect many countries, such widespread has obliged the World Health Organization (WHO) to announce it as 'pandemic' on 11 March 2020 [1]. During the pandemic, most of our daily tasks were stopped because of the lockdown procedures, which involve very restricted rules for people to keep a social distance for mitigating the virus fulmination. This issue has affected most countries all over the world, including educational institutes. Hence, it led to university closure; according to [2], such closure has several adverse impacts, depriving students of being educated. Therefore, the universities have adopted e-learning as the educational tool during the pandemic as an urgent solution to address the institutes' closure problems and related consequences [3].

E-learning techniques can play a vital role in both operations, teaching, and learning. For example, the teachers could deliver and manage their courses in various ways to be available and accessible by students anytime and anywhere, i.e., e-learning can be a ubiquitous technique $[4,5]$. Furthermore, students can use their smartphones to get their desired resources, including education tasks, quizzes, assignments, and many other related tasks [6]. In spite, e-learning has several benefits - especially during abnormal situations - however, it relies mainly on students' willingness and acceptance [7]. Therefore, the usage of e-learning systems can be combined with some challenges and constraints [8]. Iraq is one of the countries that relied on e-learning to fulfill the academic year (2020-2021) regarding the higher education institutes. However, as a developing country, Iraq suffers from a lack of e-learning support [9]. Before the pandemic, traditional education was mainly used, e-learning was used in a particular situation, or according to the teacher's perspective, but the universities do not endorse it since several limitations face the adoption of such technology [10, 11]. Within such challenging circumstances, the idea 
of adopting such a learning technique may come with several obstacles; for instance, students are not familiar with such kind of learning that depends on using the Internet and web applications along with elearning platforms. Also, the unstable situation in Iraq many years ago and the current academic year, which starts in September 2019, where there were big demonstrations against corruption in Iraq, have affected the class attending activities. All of the mentioned circumstances hindered the adoption of elearning in this country.

We adopted (TAM) methodology with some external variables. Also, we used (TTF) as a moderator to measure the attitude toward e-learning. We implemented the study on students who have been studying remotely since march 2020. The students used Google Suite for Education (G-Suite) as an e-learning platform. As a result, they have fully completed their tasks, including final exams. The good thing about the experiment is that e-learning can be an excellent tool for unusual circumstances, even in developing countries where many challenges exist. The study is organized as follows: section two is dedicated to describe the background and literature review, then section three illustrates the theoretical framework of the study, section four discusses the methodology, in section five, the testing procedure is described, and lastly, section six displays the conclusions and future trends.

\section{Background and literature review}

\subsection{Learning environment}

Electronic learning grew in tandem with the rapid advancement of technology [12]. It is commonly known by a specific platform that enables managing the educational resources, such as courses, tasks, homework, and so many other education-related tasks. Such environment is known as Leanings Management System (LMS) so that LMS is a preferable option to maintain learning resources and deliver them directly to the students [13]. Producing learning materials has progressed since the emergence of learning management systems (LMS), such as web-based and mobile applications. And with this enhancement of applications, the usage of LMS has become more sophisticated. E-learning provides educational resources and involves several ways to encourage students to use them and boost their learning performance [14].

Several studies have addressed the benefits of elearning compared to face-to-face learning, where traditional learning is challenging to be conducted in critical circumstances. Some studies have proved that e-learning could present similar performance according to the students [15]. Other studies found that the students perform better if they are involved with e-learning, and they prefer it over traditional learning $[16,17]$. E-learning presents some features that depict the development of such a learning tool. Such as enhancing the learning quality, where elearning moved to act as a learning paradigm rather than being only under instruction mode, students can be supported through their learning activities $[18,19]$. Besides, e-Learning supports modern techniques in education, such as building educational modules for a specific discipline. Also, using various learning modules helps promote the learners' critical thinking skills. Despite the benefits that e-learning provides, it also comes with some challenges. On top of them is the isolation problem, where the learner is isolated from being interactive with other students and educators so that engaging students physically can increase their enthusiasm [20-22].

E-learning presents a plausible solution to help students and teachers in crises because traditional education has a high sensitivity toward abnormal situations. These problematic situations mainly prevent the students from attending their classes, so that e-learning becomes a critical need [23].

\subsection{E-learning in Iraq}

E-learning has become the primary alternative for traditional education in educational institutions. Since the social distancing imposed by the Iraqi government to control and prevent the outbreak COVID-19 pandemic, so that the traditional mode of study in the universities has stopped and shifted to elearning. E-learning is a current topic that is widely concerned in middle east countries, especially Iraq [11], which is considering a new test with the spread of COVID-19. Google Classroom has emerged as one of the most used applications in e-learning [24]. Previous literature has discussed the challenges and difficulties in applied distance learning in developing countries. The regions, cognitive development, and cultural backgrounds can affect the performance and application of e-learning [25].

A few studies addressed e-learning in Iraq, such as in $[11,26]$, stating that Iraq represents a particular case because of facilities' political unrest. In addition, they mentioned that universities do not have the technological facilities and infrastructures due to wars and unstable situations that hindered the country's capabilities to modernize technology and adopt e-learning [27, 28]. According to [29], Iraqi universities do not have sufficient experience, possibilities, and efficient planning to deal with e- 
learning. Most of the previous studies focused on lecturers' or IT staff and infrastructure side, while some studies focused on students' perspectives about e-learning [26]. Hence this field of research needs more effort to address the main advantages and drawbacks.

From the previously mentioned issues, this study aims to cover a specific gap which is measuring the students' intention to use e-learning in one of the Iraqi educational institutes. Measuring this issue can propose some explanations that would provide specific indications regarding using this type of education in a country like Iraq and its conditions, which were previously mentioned. In addition to the use of this type under critical conditions such as the Covid-19 pandemic. We also added some external variables to the TAM model and used TTF as a moderator. We believe TTF can positively moderate the model and supports the study objectives. Although most previous studies adopted the TAM to explain the user's acceptance of new technology, it may be inappropriate for various technologies. Other studies have recommended integrating the factors of TAM with other theories' factors [30, 31].

\section{Theory}

In examining factors affecting e-learning through covid-19, this study uses the theoretical factors of the Technology Acceptance Model (TAM). TAM explores the main factors that affect a user's adoption behavior towards new technologies. TTF also added to the model as moderator,

\subsection{Technology acceptance model (TAM)}

User Acceptance can be defined as the users' opinion of the information system and to what extent it fulfills the requirements for which it is designed [32]. This model has been chosen to test diverse applications and systems in dozens of researches and has become a more popular model for measuring user acceptance and usage. TAM model has been adopted due to its quality in explaining and anticipating the features that influence a user's adoption behavior towards new technologies [33-35]. It also has been widely utilized to enhance e-learning use and acceptance [34, 36, 37]. User acceptance is essential to systems' improvement. TAM predicts user acceptance behavior through perceived ease of use and usefulness.

TAM is proposed by [38], containing the main factors of user acceptance (perceived ease of use PEOU, perceived usefulness PU, and attitudes toward using technology ATU), Fig. 1. Based on the most recent researches, this research expects to present positive relationships between the constructs mentioned above. The TAM theory assumes that PEOU and PU directly affect attitude toward the use of ATU. Furthermore, the ATU directly affects Intention to Use (IU), and the IU directly affects Actual Use (AU). The following hypotheses have been suggested:

- H1: PU has a positive effect on ATU of e-Learning.

- H2: PEOU has a positive effect on the ATU of elearning.

- H3: PEOU has a positive effect on PU of elearning.

- H4: PU has a positive effect on the IU of elearning.

- H5: ATT has a positive effect on the IU of elearning.

- H6: IU has a positive effect on the $A U$ of $e$ learning.

Indeed, the TAM did not cover general information,

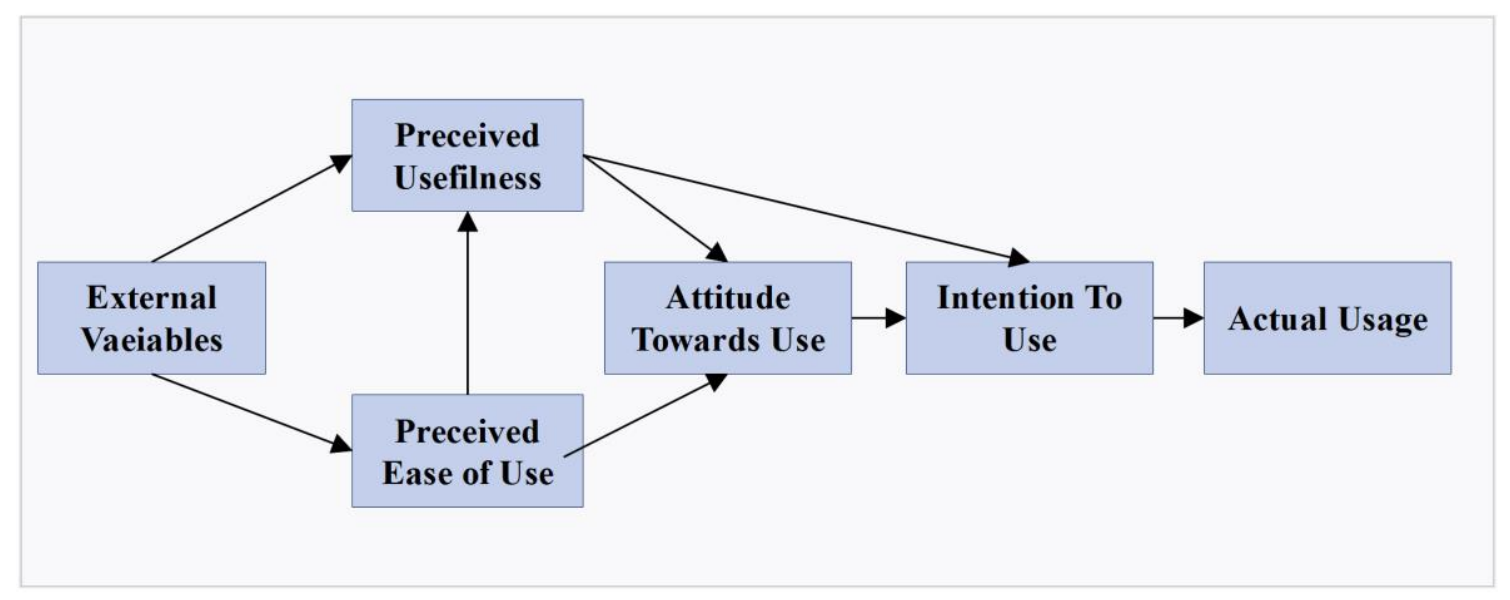

Figure. 1 Technology acceptance model (TAM) 
service, and quality, even if it significantly influenced user behavior [39]. So, the external factors have been added to improve the ability of the model to predict student's adoption and usage behavior of e-learning. The following external variables are added to our model to test their effect on the model:

\subsubsection{System quality (SQ):}

It is the suitability and accuracy of a system to meet the requirements [40]. It reflects the level of information and content provided by the e-learning system regarding its overall quality. Therefore, it is an essential factor for the adoption of e-learning systems [41]. Because e-learning is still at the infancy level in Iraq, the advanced information systems led to emerging difficulties. Hence, the researchers try to improve the new systems' quality and functionality to exploit technological growth and prospects [42]. According to [43], SQ positively affects the PEOU of the e-learning system. Therefore, this study hypothesizes the following:

- H7: SQ has a positive effect on the PU of e-learning.

- H8: SQ has a positive effect on the PEOU of elearning.

\subsubsection{Subject norms (SN):}

The extent to which close people influence a person's thinking towards a particular performance [44]. Eighty-four percent of (32) studies used SN Confirmed to have a relationship with TAM [45]. Furthermore, a study in [46] added subjective norms into TAM, demonstrating that it influences behavioral intention. Specifically, we are interested in how the opinions of their peers influence a student, and we are interested in encouraging teachers to adopt e-learning in an academic setting. Therefore, it can be defined as the extent of the student's orientation towards e-learning in light of the external environment represented by peer pressure [47]. Therefore, this study hypothesizes the following:

- H9: SN has a positive effect on PU for e-learning.

- H10: SN has a positive effect on PEOU for elearning.

\subsubsection{Computer playfulness $(\mathrm{CP})$ :}

This is defined as "the degree of cognitive spontaneity in microcomputer interaction" [48]. Playfulness involves concepts such as curiosity, discovery, examination, and difficulty. In the initial stages of system acceptance, an individual's playfulness is necessary [49]. In technology systems, systems should be based on a sufficient and satisfactory basis to be perceived and used. Regardless of the system's performance results, it measures whether the system is enjoyable in its own right [50]. Individuals who interacted with new technology as a playfulness were more optimistic than individuals who interacted less playfully [51]. Therefore, if the students find playfulness using the learning system, their attitude and intent will be more positive. Many studies show a positive relationship between the $\mathrm{CP}$ and $\mathrm{PU}$, which increases the intention of the student to use e-learning [52]. Therefore, this study hypothesizes the following:

\section{- H11: There is a positive relationship between CP and $P U$}

- H12: There is a positive relationship between CP and PEOU

\subsubsection{Self-efficacy (SE):}

Individuals' confidence in their abilities to plan and carry out the courses of action necessary to achieve specified goals [53]. SE is used to determine an individual's emotions and behavioral patterns. Various studies stated that self-efficacy had a significant impact on the perceived ease of use and perceived utility of e-learning $[54,55]$. As a result, the following hypotheses are proposed in this study:

- H13: SE has a positive effect on PU for e-learning.

- H14: SE has a positive effect on PEOU for elearning.

\subsubsection{Accessibility (ACC):}

A system that is easily accessible can be utilized more smoothly and frequently than an inaccessible system and creates barriers in the user's journey through it [50]. The greater the accessibility of an elearning system, the greater the likelihood that students will recognize the ease with which the technology may be used [56]. However, many problems hinder access to the system, such as poor internet services, lack of technical infrastructure, and power outages. As a result, the student tends not to use e-learning due to network connectivity problems, poor internet services, internet interruptions, or reliable access to educational sites [57]. Therefore, this study hypothesizes the following:

- H15: ACC has a positive effect on PU for elearning.

- H16: ACC has a positive effect on PEOU for elearning. 


\subsection{Task technology fit (TTF)}

In addition to the TAM model, it is also relevant to test the TTF as a moderator factor that may enhance or hinder user satisfaction. The new technology will not be adopted if it's not met users' requirements [58]. The study in [59] stated that the TTF model is more understanding and suitable for adopting learning management systems. In addition, it has a statistically significant and positive impact on the utilization of learning performance systems. In addition, [60] confirmed that TTF was used to evaluate technology use on users' performance by comparing the task and technology quality. The TTF is essential as it measures to what extent the technology has met requirements [61]. Therefore, TTF moderators are expected to affect the attitude toward using e-learning significantly. Accordingly, our study hypothesizes the following:

- H17: TTF has a positive effect on IU for e-learning.

- H18: TTF will moderate the effects of Attitude toward use on intention to use e-learning; the effects will be more substantial among users with higher TTF.

\section{Methodology}

\subsection{Research sample and data collection}

The educational cycle in Iraq mainly consists of two stages. The first stage is primary education, supervised by the Iraqi Ministry of Education. It consists of twelve years, including six years of primary education, which starts from the age of six, followed by three years of intermediate education, and then three years of secondary education, divided into two branches, scientific or literary. Students who finish secondary school can obtain the minimum qualifications to continue in the second stage, which is the stage of higher education, under the supervision of the Iraqi Ministry of Higher Education. A student who holds a secondary qualification can study in a higher education institution -depending on hislher GPA- which may be technical institutes (a study for at least two years and a technical diploma is awarded). Or colleges (in which the study period is four years as a minimum, except for some medical specialties, and the graduate is awarded a certificate Bachelor's degree in a specific discipline.

As mentioned before, we conducted our research at Technical College of Management- Baghdad, Middle Technical University, one of Iraq's public universities. The students in this college are divided among five scientific departments: Bussiness Administration Techniques, Accounting Techniques, Information Technology, Banking and Funding Techniques, and Total Quality Management Techniques. A graduate student will be rewarded with a Bachelor's degree in one of the disciplines

Table 1. Demographic information

\begin{tabular}{clcc}
\hline Item & \multicolumn{1}{c}{ Characteristics } & No. & Percentage \\
\hline \multirow{2}{*}{ Gender } & Female & 197 & $53 \%$ \\
& Male & 172 & $47 \%$ \\
& Accounting Techniques & 67 & $18 \%$ \\
& Banking and Funding Techniques & 59 & $16 \%$ \\
Departments & Business Administration & 77 & $21 \%$ \\
& Information Technology & 93 & $25 \%$ \\
& Total Quality Techniques & 73 & $20 \%$ \\
Age & 22-27 years pld & 146 & $40 \%$ \\
& Less than 22 years old & 206 & $56 \%$ \\
& More than 27 years old & 17 & $5 \%$ \\
PC Using Skills & Beginner & 73 & $20 \%$ \\
& Excellent & 71 & $19 \%$ \\
No. of courses & Medium & 225 & $61 \%$ \\
during Covid- & 1-2 Courses & 69 & $19 \%$ \\
19 & More than 5 Courses & 61 & $17 \%$ \\
& 1st Year & 239 & $65 \%$ \\
Study Year & 2nd Year & 199 & $54 \%$ \\
& 3rd Year & 20 & $5 \%$ \\
4th Year & 87 & $24 \%$ \\
Teb apps using & I have a Basic experience & 63 & $17 \%$ \\
skills & I have a Fair experience & 129 & $35 \%$ \\
& I have a Good experience & 162 & $44 \%$ \\
& & 78 & $21 \%$ \\
& & $\mathbf{3 6 9}$ & $\mathbf{1 0 0 . 0 \%}$ \\
\hline
\end{tabular}


Table 2. Model assessment information

\begin{tabular}{|c|c|c|c|c|c|c|}
\hline Factor & Indicator & Loadings & Mean & $\begin{array}{c}\text { Cronbach's } \\
\text { Alpha }\end{array}$ & CR & AVE \\
\hline \multirow{4}{*}{$\begin{array}{l}\text { Accessibility } \\
\text { ACC }\end{array}$} & ACC1 & 0.839 & \multirow{4}{*}{0.859} & \multirow{4}{*}{0.823} & \multirow{4}{*}{0.894} & \multirow{4}{*}{0.738} \\
\hline & $\mathrm{ACC} 2$ & 0.859 & & & & \\
\hline & ACC3 & 0.879 & & & & \\
\hline & ATU1 & 0.852 & & & & \\
\hline \multirow{3}{*}{$\begin{array}{c}\text { Attitude Toward Using } \\
\text { ATU }\end{array}$} & ATU2 & 0.861 & \multirow{3}{*}{0.855} & \multirow{3}{*}{0.877} & \multirow{3}{*}{0.916} & \multirow{3}{*}{0.730} \\
\hline & ATU3 & 0.834 & & & & \\
\hline & ATU4 & 0.871 & & & & \\
\hline Actual Use & AU1 & 0.851 & \multirow{2}{*}{0.880} & \multirow{2}{*}{0.712} & \multirow{2}{*}{0.873} & \multirow{2}{*}{0.774} \\
\hline AU & AU2 & 0.908 & & & & \\
\hline \multirow{3}{*}{$\begin{array}{l}\text { Computer Playfulness } \\
\text { CP }\end{array}$} & $\mathrm{CP} 1$ & 0.855 & \multirow{3}{*}{0.851} & \multirow{3}{*}{0.81} & \multirow{3}{*}{0.888} & \multirow{3}{*}{0.725} \\
\hline & $\mathrm{CP} 2$ & 0.817 & & & & \\
\hline & $\mathrm{CP} 3$ & 0.881 & & & & \\
\hline \multirow{3}{*}{$\begin{array}{l}\text { Intention to Use } \\
\text { IU }\end{array}$} & IU1 & 0.827 & \multirow{4}{*}{0.837} & \multirow{3}{*}{0.787} & & \\
\hline & IU2 & 0.861 & & & 0.875 & 0.701 \\
\hline & IU3 & 0.823 & & & & \\
\hline & PEOU1 & 0.832 & & & & \\
\hline & PEOU2 & 0.816 & & & & \\
\hline Perceived Ease of Use & PEOU3 & 0.822 & 0.820 & 0.879 & 0.911 & 0.673 \\
\hline & PEOU4 & 0.810 & & & & \\
\hline & PEOU5 & 0.822 & & & & \\
\hline & PU1 & 0.864 & & & & \\
\hline & PU2 & 0.869 & & & & \\
\hline Perceived Usefulness & PU3 & 0.740 & 0.822 & 0.88 & 0.913 & 0.678 \\
\hline & PU4 & 0.811 & & & & \\
\hline & PU5 & 0.828 & & & & \\
\hline & SE1 & 0.795 & & & & \\
\hline Self-Efficacy & SE2 & 0.852 & & & & 0601 \\
\hline SE & SE3 & 0.840 & 0.831 & 0.851 & 0.899 & 0.691 \\
\hline & SE4 & 0.837 & & & & \\
\hline & SN1 & 0.800 & & & & \\
\hline Subjective Norms & SN2 & 0.826 & 0818 & & & 0670 \\
\hline $\mathrm{SN}$ & SN3 & 0.833 & 0.818 & 0.836 & 0.89 & 0.670 \\
\hline & SN4 & 0.814 & & & & \\
\hline & SQ1 & 0.737 & & & & \\
\hline & SQ2 & 0.765 & & & & \\
\hline System Quality & SQ3 & 0.807 & 0.796 & 0.855 & 0.897 & 0.635 \\
\hline & SQ4 & 0.836 & & & & \\
\hline & SQ5 & 0.834 & & & & \\
\hline & TTF1 & 0.761 & & & & \\
\hline & TTF2 & 0.723 & & & & \\
\hline & TTF3 & 0.773 & & & & \\
\hline & TTF4 & 0.773 & & 000 & ר0 ר & 0500 \\
\hline $\mathrm{TTF}$ & TTF5 & 0.818 & 0.767 & 0.900 & 0.92 & 0.589 \\
\hline & TTF6 & 0.773 & & & & \\
\hline & TTF7 & 0.741 & & & & \\
\hline & TTF8 & 0.773 & & & & \\
\hline
\end{tabular}

above.

The data collection phase has been performed using an online questionnaire due to the lockdown procedures and considering the online tools to perform most educational institutes' tasks. The students who are involved in the questionnaire were in the academic year (2019-2020). Due to the Covid19 Pandemic, the ministry of higher education in Iraq decided to convert the whole educational procedure to e-learning platforms, including final exams. The research society is composed of undergraduate students, the population size is (3948), according to $[62,63]$, the sample size is advised to be in the range (350-380). The questionnaire was distributed at the end of the final exam. All students have thoroughly worked with e-learning platforms for about five 
months to understand the posed items and answer correctly. After the questionnaire distribution, (369) individuals have responded successfully.

As stated in Table 1, most of the research sample were females $(58.41 \%)$, and the higher responses were from the Accounting Techniques Department and the Total Quality Techniques Department. Also, respondents' age was majorly from less than (22) years old with $(55.83 \%)$, which is typical for all students in the undergraduate study. Besides, about $(61 \%)$ of the respondents have mostly had medium knowledge of using computers. The same thing happened with the experience of using web apps, so that most of the respondents have had a medium level of expertise. Regarding the courses that the respondents studied, most students studied more than five courses within the last few months. Among the respondents, $(54 \%)$ were in the first academic year compared to other students.

\subsection{Model assessment}

Our research utilizes the most well-known tool for modeling and analyzing: Partial Least Squares (PLS) [64]. We select this tool due to its privileges in terms of availability. Such software is available and easy to get for academics and researchers, and its usability in modeling and reporting. Furthermore, the software is being widely used in many types of research that deal with analyzing and modeling.
For the model assessment, we perform an outer loading assessment throughout measuring the scales of reliability to confirm the indicator's properties and state the relationships among them [65]. On the other hand, convergent validity is also used to test theloadings' strength, as stated in Table 2. the Cronbach's Alpha values, along with Composite Reliability (CR) values and for all of the factors, are above the acceptable rate, which is (0.7). Also, all of the rates of Average Variance Extracted (AVE) are above (0.5), which indicates the model is reliable and satisfactory $[65,66]$. To verify the model entirely, we examined the factor loading for all of the factors in Table 2. The results prove the consistency between the model factor since all the loading factors above the threshold are (0.7) [67].

Furthermore, the discriminate validity is also tested, which refers to the corresponding correlations. We utilize the Heterotrait-Monotrait Ratio of Correlations (HTMT), which is considered one of the latest methods that examined the discriminant validity. It represents an excellent method for model evaluation. Implementing such a process ensures the model and leaves no doubts for the researcher about his model [68]. If the (HTMT) calculation is below one, discriminate validity persists and vice versa [69]. Similarly, the Fornell-Larcker criterion is also tested to identify the discriminant validity of the model, Tables 3 and 4 .

Table 3. Heterotrait-monotrait ratio (HTMT)

\begin{tabular}{cccccccccccc}
\hline & ACC & AU & ATU & CP & PEOU & IU & PU & SE & SN & SQ & TTF \\
\hline ACC & & & & & & & & & & & \\
AU & $\mathbf{0 . 4 7 7}$ & & & & & & & & & & \\
ATU & 0.682 & $\mathbf{0 . 4 9 6}$ & & & & & & & & & \\
CP & 0.822 & 0.522 & $\mathbf{0 . 8 3}$ & & & & & & & & \\
PEOU & 0.79 & 0.544 & 0.725 & $\mathbf{0 . 7 9 1}$ & & & & & & & \\
IU & 0.777 & 0.521 & 0.748 & 0.925 & $\mathbf{0 . 7 1 5}$ & & & & & & \\
PU & 0.65 & 0.514 & 0.813 & 0.823 & 0.748 & $\mathbf{0 . 8 2 4}$ & & & & & \\
SE & 0.71 & 0.571 & 0.669 & 0.727 & 0.683 & 0.708 & $\mathbf{0 . 7 0 8}$ & & & & \\
SN & 0.699 & 0.555 & 0.636 & 0.775 & 0.787 & 0.798 & 0.763 & $\mathbf{0 . 7 8 0}$ & & & \\
SQ & 0.752 & 0.514 & 0.795 & 0.889 & 0.771 & 0.856 & 0.807 & 0.74 & $\mathbf{0 . 7 8 4}$ & & \\
TTF & 0.756 & 0.589 & 0.715 & 0.844 & 0.814 & 0.901 & 0.814 & 0.767 & 0.967 & $\mathbf{0 . 9 5 5}$ & \\
\hline
\end{tabular}

Table 4. Fornell-larcker scale

\begin{tabular}{cccccccccccc}
\hline & ACC & AU & ATU & CP & PEOU & IU & PU & SE & SN & SQ & TTF \\
\hline ACC & $\mathbf{0 . 8 5 9}$ & & & & & & & & & & \\
AU & 0.367 & $\mathbf{0 . 8 8 0}$ & & & & & & & & & \\
ATU & 0.579 & 0.391 & $\mathbf{0 . 8 5 5}$ & & & & & & & & \\
CP & 0.672 & 0.398 & 0.702 & $\mathbf{0 . 8 5 2}$ & & & & & & & \\
PEOU & 0.674 & 0.431 & 0.639 & 0.669 & $\mathbf{0 . 8 2 0}$ & & & & & & \\
IU & 0.628 & 0.395 & 0.623 & 0.739 & 0.596 & $\mathbf{0 . 8 3 7}$ & & & & & \\
PU & 0.554 & 0.409 & 0.714 & 0.696 & 0.659 & 0.686 & $\mathbf{0 . 8 2 4}$ & & & & \\
SE & 0.598 & 0.447 & 0.581 & 0.606 & 0.593 & 0.582 & 0.614 & $\mathbf{0 . 8 3 1}$ & & & \\
SN & 0.583 & 0.431 & 0.545 & 0.639 & 0.675 & 0.649 & 0.656 & 0.660 & $\mathbf{0 . 8 1 8}$ & & \\
SQ & 0.633 & 0.407 & 0.690 & 0.742 & 0.670 & 0.705 & 0.701 & 0.633 & 0.665 & $\mathbf{0 . 7 9 7}$ & \\
TTF & 0.653 & 0.478 & 0.637 & 0.721 & 0.725 & 0.760 & 0.725 & 0.673 & 0.840 & 0.838 & $\mathbf{0 . 7 6 7}$ \\
\hline
\end{tabular}


Table 5. Model hypotheses testing results

\begin{tabular}{cccccccc}
\hline H\# & Hypothesis & $\begin{array}{c}\boldsymbol{\beta} \\
\text { Path }\end{array}$ & Mean & STD & $\begin{array}{c}\text { T } \\
\text { Values }\end{array}$ & $\begin{array}{c}\text { P } \\
\text { Values }\end{array}$ & Decision \\
\hline $\mathbf{1}$ & PU $\rightarrow$ ATU & 0.517 & 0.515 & 0.052 & 10.033 & 0.000 & Accepted \\
$\mathbf{2}$ & PEOU $\rightarrow$ ATU & 0.298 & 0.301 & 0.050 & 5.935 & 0.000 & Accepted \\
$\mathbf{3}$ & PEOU $\rightarrow$ PU & 0.186 & 0.186 & 0.064 & 2.900 & 0.004 & Accepted \\
$\mathbf{4}$ & PU $\rightarrow$ IU & 0.195 & 0.197 & 0.056 & 3.504 & 0.000 & Accepted \\
$\mathbf{5}$ & ATU $\rightarrow$ IU & 0.147 & 0.146 & 0.059 & 2.494 & 0.013 & Accepted \\
$\mathbf{6}$ & IU $\rightarrow$ AU & 0.395 & 0.395 & 0.041 & 9.542 & 0.000 & Accepted \\
$\mathbf{7}$ & SQ $\rightarrow$ PU & 0.238 & 0.236 & 0.064 & 3.730 & 0.000 & Accepted \\
$\mathbf{8}$ & SQ $\rightarrow$ PEOU & 0.171 & 0.167 & 0.065 & 2.634 & 0.009 & Accepted \\
$\mathbf{9}$ & SN $\rightarrow$ PU & 0.160 & 0.165 & 0.067 & 2.390 & 0.017 & Accepted \\
$\mathbf{1 0}$ & SN $\rightarrow$ PEOU & 0.270 & 0.266 & 0.060 & 4.513 & 0.000 & Accepted \\
$\mathbf{1 1}$ & $\mathrm{CP} \rightarrow$ PU & 0.260 & 0.262 & 0.058 & 4.491 & 0.000 & Accepted \\
$\mathbf{1 2}$ & $\mathrm{CP} \rightarrow$ PEOU & 0.155 & 0.165 & 0.063 & 2.474 & 0.014 & Accepted \\
$\mathbf{1 3}$ & $\mathrm{SE} \rightarrow$ PU & 0.131 & 0.132 & 0.053 & 2.459 & 0.014 & Accepted \\
$\mathbf{1 4}$ & $\mathrm{SE} \rightarrow$ PEOU & 0.048 & 0.049 & 0.059 & 0.822 & 0.411 & Not Accepted \\
$\mathbf{1 5}$ & ACC $\rightarrow$ PU & -0.068 & -0.075 & 0.058 & 1.164 & 0.245 & Not Accepted \\
$\mathbf{1 6}$ & ACC $\rightarrow$ PEOU & 0.275 & 0.275 & 0.052 & 5.253 & 0.000 & Accepted \\
$\mathbf{1 7}$ & TTF $\rightarrow$ IU & 0.543 & 0.540 & 0.053 & 10.155 & 0.000 & Accepted \\
$\mathbf{1 8}$ & Moderator TTF $\rightarrow$ IU & $\mathbf{0 . 0 6 6}$ & $\mathbf{0 . 0 6 5}$ & $\mathbf{0 . 0 3 3}$ & $\mathbf{1 . 9 7 1}$ & $\mathbf{0 . 0 4 9}$ & Accepted \\
\hline
\end{tabular}

\section{Hypotheses testing}

Fig. 2 and Table 5 display the model assessments and finding. The results were gained by running bootstrapping algorithm using PLS with (500) subsamples and significance level (0.05). As stated before, (18) hypotheses were formulated to assess our model, from the given results, (16) out (18) hypotheses were accepted. And this supports the model's aims, which seeks the students' acceptance in adopting e-learning during particular situations.

For $(\mathrm{H} 1, \mathrm{H} 2)$, we can see that the perceived usefulness and perceived ease to use are positively affect the students' attitude toward using the elearning, which is proved by the values of $(\beta=0.517$, $\beta=0.298)$ respectively where $(p<0.05)$. The results of $(\mathrm{H} 1, \mathrm{H} 2)$ support that the student think that elearning is somehow easy to use, so they easily adopt such a mode of study. Regarding (H3), the result states that the students think that the perceived ease to use positively affects the perceived usefulness, where the testing values were at $(\beta=0.186, p<0.05)$. Generally, and for the hypotheses (H4, H5, H6, H7, H8, H9, H10, H11, H12, H13, H16, H17, H18), we can see according to the value of $(\beta)$, all of them are accepted. By recalling the hypotheses, we can say that the model satisfies its purpose. So that, for different factors like subjective norms, system quality, computer playfulness, and so on, all of them presented promising results in terms of perceived usefulness and eased to use. Only two hypotheses were rejected, which are $(\mathrm{H} 14, \mathrm{H} 15)$ so that the values of $(\beta)$ come at the rate of $(\beta=0.048, \beta=-$ $0.068)$ respectively where $(\mathrm{p}<0.05)$. The first value is related to the idea that (Self-Efficacy positively affects the perceived ease to use) so that the students think that this factor does not meet their requirements. It might be because of their knowledge about using such a learning system that they were unfamiliar with previously. The other rejected hypothesis is regarding the accuracy of e-learning and its relation to the perceived usefulness. The students believe that no such usefulness is related to accuracy. This thing also related to the lack of using technology. Since people usually doubt about trying new scenarios. Where the students concern about learning accuracy because it deals with their marks and eventually their certificates. Despite that, only two hypotheses were rejected; however, most were accepted.

\section{Conclusion and future trends}

Regarding the results, it is noteworthy to say that the model presented plausible results. The students are generally using e-learning as an alternative learning paradigm during abnormal situations and crises. E-learning brings valuable features that can be utilized efficiently to enrich the teaching experience since it produces many valuable solutions. Five external variables were added to the model; three of them have significant effects on the (PU \& PEOU), 


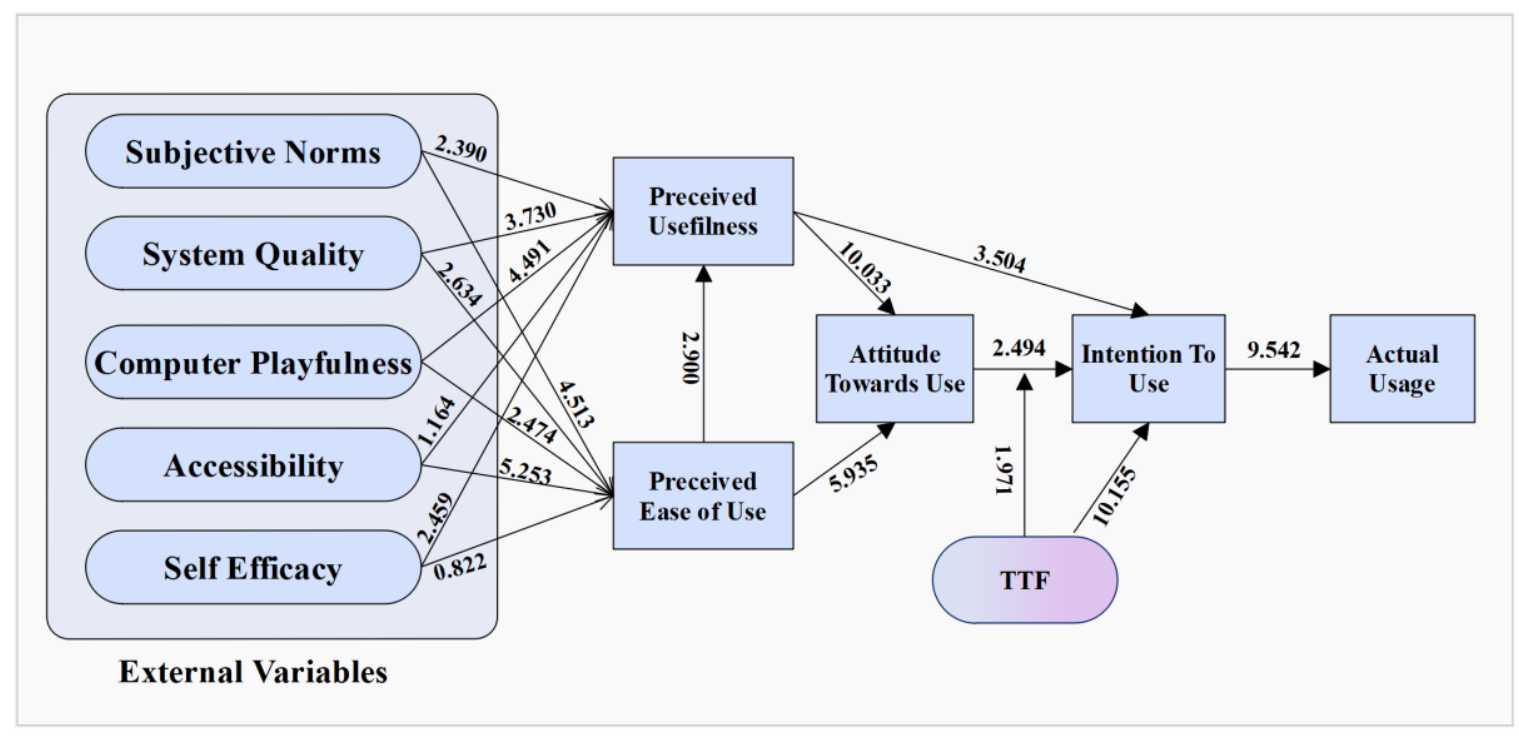

Figure. 2 Model simulation results

which indicates that the students were more motivated to use the e-learning paradigm during the pandemic. On the other hand, two variables presented less effectively according to the model are (Accessibility and Self Efficacy). Since the ACC is more about the system performance in providing the resources, and since e-learning depending mainly on the internet connectivity performance, we think that due to the low efficient internet services in Iraq, the students were not agreed with the accessibility issue. Also, regarding SE, which is related to the confidence level of the students to use e-learning, the disagreement of the student is because of the new experiment of such learning mode, where they might be concern about their outcomes when using such a new trend which they are not familiar to use. One of the points this study seeks to state is the effect of TTF can positively moderate the TAM model. And according to the results gained, TTF is affecting the model positively and significantly.

Despite that, there are some limitations in adopting e-learning in full mode, but it can be more effective if utilized to bring it to the right way. Some features of e-learning produced less rate in terms of significance, such as accuracy and self-efficacy. However, many other features are pretty plausible. Therefore, the model results open the doors toward exploring more features and measuring more aspects of adopting e-learning during crises.

\section{Conflicts of interest}

"The authors declare no conflict of interest."

\section{Author contributions}

All of the authors have contributed to perform this research since all of them work at the same organization. Therefore, the roles of performing this research can be stated as follows: Conceptualization, Mohammed Fadhil Ibrahim, and Huda Khurshed Shawkat Aljader; methodology, Nawar Abbood Fadhil; PLS and results from the analysis, Mohammed Fadhil Ibrahim; validation, Mohammed Fadhil Ibrahim, Huda Khurshed Shawkat Aljader, and Nawar Abbood Fadhil; resources, Nawar Abbood Fadhil; data collection Mohammed Fadhil Ibrahim, Huda Khurshed Shawkat Aljader; writing original draft preparation, Mohammed Fadhil Ibrahim, Huda Khurshed Shawkat Aljader; visualization, Nawar Abbood Fadhil.

\section{References}

[1] G. TD, "WHO Director-General's opening remarks at the media briefing on COVID-19 - 11 March 2020", World Health Organization (WHO).

https://www.who.int/dg/speeches/detail/whodirector-general-s-opening-remarks-at-themedia-briefing-on-covid-19---11-march-2020 (accessed 11 June 2020.

[2] UNESCO. "Education: From disruption to recovery",

UNESCO https://en.unesco.org/covid19/educationrespons e (accessed 15 June 2020.

[3] M. A. Almaiah and A. A. Khasawneh, "Investigating the main determinants of mobile 
cloud computing adoption in university campus", Education and Information Technologies, pp. 121, 2020.

[4] L. Poinsignon. "On the shoulders of giants: recent changes in Internet traffic", Cloudflare. https://blog.cloudflare.com/on-the-shouldersof-giants-recent-changes-in-internet-traffic/ (accessed 20 May 2020.

[5] T. Favale, F. Soro, M. Trevisan, I. Drago, and M. Mellia, "Campus traffic and e-Learning during COVID-19 pandemic", Computer Networks, Vol. 176, p. 107290, 2020.

[6] M. Haghshenas, "A model for utilizing social Softwares in learning management system of Elearning", Quarterly of Iranian Distance Education Journal, Vol. 1, No. 4, pp. 25-38, 2019.

[7] M. A. Almaiah and A. A. Khasawneh, "Investigating the main determinants of mobile cloud computing adoption in university campus", Education and Information Technologies, Vol. 25, No. 4, pp. 3087-3107, 2020.

[8] N. Hasan and Y. Bao, "Impact of "e-Learning crack-up" perception on psychological distress among college students during COVID-19 pandemic: A mediating role of "fear of academic year loss" ", Children and Youth Services Review, Vol. 118, p. 105355, 2020.

[9] M. M. Jæger and E. H. Blaabæk, "Inequality in learning opportunities during Covid-19: Evidence from library takeout", Research in Social Stratification and Mobility, Vol. 68, p. 100524, 2020.

[10] M. A. Mahmod, A. B. M. Ali, A. Shah, and M. S. A. Seman, "E-learning in Iraqi universities: A review", in 2017 International Conference on Computing, Engineering, and Design (ICCED), 2017: IEEE, pp. 1-4.

[11] A. A. Azawei, P. Parslow, and K. Lundqvist, "Barriers and opportunities of e-learning implementation in Iraq: A case of public universities", The International Review of Research in Open and Distributed Learning, Vol. 17, No. 5, 2016.

[12] V. Tabakova, "E-learning - from first experiences in medical physics and engineering to its role in times of crisis", Health and Technology, Vol. 10, No. 6, pp. 1385-1390, 2020.

[13] R. Estriegana, J. A. M. Merodio, and R. Barchino, "Student acceptance of virtual laboratory and practical work: An extension of the technology acceptance model", Computers \& Education, Vol. 135, pp. 1-14, 2019.
[14] I. Almarashdeh, "Sharing instructors experience of learning management system: A technology perspective of user satisfaction in distance learning course", Computers in Human Behavior, Vol. 63, pp. 249-255, 2016.

[15] I. E. Allen and J. Seaman, Learning on demand: Online education in the United States, 2009. ERIC, 2010.

[16] A. E. Mhouti, M. Erradi, and A. Nasseh, "Using cloud computing services in e-learning process: Benefits and challenges", Education and Information Technologies, Vol. 23, No. 2, pp. 893-909, 2018.

[17] S. Gautam and M. K. Tiwari, "Components and benefits of E-learning system", Journal of Computer Science, Vol. 3, No. 1, pp. 2014-2017, 2016.

[18] J. Stephenson, Teaching \& learning online: new pedagogies for new technologies. Routledge, 2018.

[19] S. Alexander, "E-learning developments and experiences", Education+ Training, 2001.

[20] B. Mourad, A. Tarik, A. Karim, and E. Pascal, "System interactive cyber presence for E learning to break down learner isolation", arXiv preprint arXiv:1502.06641, 2015.

[21] S. Leone and T. Leo, "Characterisation of a Personal Learning Environment as a lifelong learning tool", Doctoral School on Engineering Sciences, 2011.

[22] M. Montebello, "E-learning paradigms: A model to address known issues", in 2017 Computing Conference, 18-20 , pp. 1180-1189, 2017.

[23] M. M. Gray, R. Dadiz, S. Izatt, M. G. Krakauer, M. M. Carbajal, A. J. Falck, E. M. Bonachea, L. C. Johnston, H. Karpen, M. M. Vasquez, P. R. Chess, and H. French, "Value, Strengths, and Challenges of e-Learning Modules Paired with the Flipped Classroom for Graduate Medical Education: A Survey from the National Neonatology Curriculum", (in En), $A m \quad J$ Perinatol, No. EFirst.

[24] [24] G. De Vynck and M. Bergen, "Google classroom users doubled as quarantines spread," Boomberg. Retrieved September, vol. 11, p. 2020, 2020.

[25] B. Rahmi and B. Birgören, "Analysis of the Studies on E-learning Acceptance of Learners in the Middle East and the Proposal of an Extended Technology Acceptance Model", Kastamonu Eğitim Dergisi, Vol. 28, No. 5, pp. 1977-1986, 2020.

[26] N. Ameen, R. Willis, M. N. Abdullah, and M. Shah, "Towards the successful integration of e- 
learning systems in higher education in Iraq: A student perspective", British Journal of Educational Technology, Vol. 50, No. 3, pp. 1434-1446, 2019.

[27] N. Ameen, "Arab users' acceptance and use of mobile phones: a case of young users in Iraq, Jordan and UAE", Doctoral Dissertation, Anglia Ruskin University, 2017.

[28] H. J. Hadi, M. A. Omar, W. R. S. Osman, M. F. Ibrahim, and M. Hussaini, "Performing a Content Validity: Establishing a Reliable Instrument to Measure the Intention to Adopt Cloud Computing Software as A Service in Public Organization", Journal of Theoretical and Applied Information Technology, Vol. 98, No. 22, 2020.

[29] D. S. Sabr and A. F. Neamah, "Notice of Violation of IEEE Publication Principles: Challenges and Opportunities of E-Learning in Iraq", in 2017 International Conference on Computer and Applications (ICCA), 6-7, pp. 259-265, 2017.

[30] B. C. Hardgrave, F. D. Davis, and C. K. Riemenschneider, "Investigating determinants of software developers' intentions to follow methodologies", Journal of management information systems, Vol. 20, No. 1, pp. 123-151, 2003.

[31] Y. H. Lee, Y. C. Hsieh, and C. N. Hsu, "Adding innovation diffusion theory to the technology acceptance model: Supporting employees' intentions to use e-learning systems", Journal of Educational Technology \& Society, Vol. 14, No. 4, pp. 124-137, 2011.

[32] B. Ives, M. H. Olson, and J. J. Baroudi, "The measurement of user information satisfaction", Communications of the ACM, Vol. 26, No. 10, pp. 785-793, 1983.

[33] N. Marangunić and A. Granić, "Technology acceptance model: a literature review from 1986 to 2013", Universal access in the information society, Vol. 14, No. 1, pp. 81-95, 2015.

[34] B. Wu and C. Zhang, "Empirical study on continuance intentions towards E-Learning 2.0 systems", Behaviour \& Information Technology, Vol. 33, No. 10, pp. 1027-1038, 2014.

[35] R. Rauniar, G. Rawski, J. Yang, and B. Johnson, "Technology acceptance model (TAM) and social media usage: an empirical study on Facebook", Journal of Enterprise Information Management, Vol. 27, No. 1, pp. 6-30, 2014.

[36] S. S. A. Gahtani, "Empirical investigation of elearning acceptance and assimilation: A structural equation model", Applied Computing and Informatics, Vol. 12, No. 1, pp. 27-50, 2016.
[37] A. Tarhini, K. Hone, and X. Liu, "The effects of individual differences on e-learning users' behaviour in developing countries: A structural equation model", Computers in human behavior, Vol. 41, pp. 153-163, 2014.

[38] F. D. Davis, "Perceived Usefulness, Perceived Ease of Use, and User Acceptance of Information Technology", MIS Quarterly, Vol. 13, No. 3, pp. 319-340, 1989.

[39] B. H. Wixom and P. A. Todd, "A theoretical integration of user satisfaction and technology acceptance", Information systems research, Vol. 16, No. 1, pp. 85-102, 2005.

[40] W. H. DeLone and E. R. McLean, "The DeLone and McLean model of information systems success: a ten-year update", Journal of management information systems, Vol. 19, No. 4, pp. 9-30, 2003.

[41] M. Aparicio, F. Bacao, and T. Oliveira, "Grit in the path to e-learning success", Computers in Human Behavior, Vol. 66, pp. 388-399, 2017.

[42] W. T. Wang and Y. J. Lai, "Examining the adoption of KMS in organizations from an integrated perspective of technology, individual, and organization", Computers in Human Behavior, Vol. 38, pp. 55-67, 2014.

[43] B. Rym, B. Olfa, and B. M. B. Mélika, "Determinants of e-learning acceptance: an empirical study in the Tunisian context", American Journal of Industrial and Business Management, Vol. 3, No. 3, pp. 307-321, 2013.

[44] S. Y. Park, M. W. Nam, and S. B. Cha, 'University students' behavioral intention to use mobile learning: Evaluating the technology acceptance model", British journal of educational technology, Vol. 43, No. 4, pp. 592605, 2012.

[45] F. Abdullah and R. Ward, "Developing a General Extended Technology Acceptance Model for E-Learning (GETAMEL) by analysing commonly used external factors," Computers in human behavior, Vol. 56, pp. 238256, 2016.

[46] R. A. Sánchez and A. D. Hueros, "Motivational factors that influence the acceptance of Moodle using TAM", Computers in human behavior, Vol. 26, No. 6, pp. 1632-1640, 2010.

[47] Á. F. A. Peregrina, Á. H. García, and F. J. P. Miguel, "Behavioral intention, use behavior and the acceptance of electronic learning systems: Differences between higher education and lifelong learning", Computers in Human Behavior, Vol. 34, pp. 301-314, 2014.

[48] F. Calisir, C. Altin Gumussoy, A. E. Bayraktaroglu, and D. Karaali, "Predicting the 
intention to use a web-based learning system: Perceived content quality, anxiety, perceived system quality, image, and the technology acceptance model", Human Factors and Ergonomics in Manufacturing \& Service Industries, Vol. 24, No. 5, pp. 515-531, 2014.

[49] C. T. Chang, J. Hajiyev, and C. R. Su, "Examining the students' behavioral intention to use e-learning in Azerbaijan? The general extended technology acceptance model for elearning approach", Computers \& Education, Vol. 111, pp. 128-143, 2017.

[50] Y. Park, H. Son, and C. Kim, "Investigating the determinants of construction professionals' acceptance of web-based training: An extension of the technology acceptance model", Automation in construction, Vol. 22, pp. 377386, 2012.

[51] J. W. Moon and Y. G. Kim, "Extending the TAM for a World-Wide-Web context", Information \& management, Vol. 38, No. 4, pp. 217-230, 2001.

[52] Y. W. Liao, Y. M. Huang, and Y. S. Wang, "Factors affecting students' continued usage intention toward business simulation games: an empirical study", Journal of Educational Computing Research, Vol. 53, No. 2, pp. 260283, 2015.

[53] A. Bandura, W. Freeman, and R. Lightsey, Selfefficacy: The exercise of control. Springer, 1999.

[54] I. Akman and C. Turhan, "User acceptance of social learning systems in higher education: an application of the extended Technology Acceptance Model", Innovations in Education and Teaching International, Vol. 54, No. 3, pp. 229-237, 2017.

[55] W. M. Rodgers, M. Conner, and T. C. Murray, "Distinguishing among perceived control, perceived difficulty, and self-efficacy as determinants of intentions and behaviours", British journal of social psychology, Vol. 47, No. 4, pp. 607-630, 2008.

[56] R. A. Sánchez, A. D. Hueros, and M. G. Ordaz, "E-learning and the University of Huelva: a study of WebCT and the technological acceptance model", Campus-Wide Information Systems, Vol. 30, No. 2, pp. 135-160, 2013.

[57] M. A. Musa and M. S. Othman, "Critical success factor in e-Learning: an examination of technology and student factors", International Journal of Advances in Engineering \& Technology, Vol. 3, No. 2, p. 140, 2012.

[58] T. Zhou, Y. Lu, and B. Wang, "Integrating TTF and UTAUT to explain mobile banking user adoption", Computers in human behavior, Vol. 26, No. 4, pp. 760-767, 2010.

[59] T. J. McGill and J. E. Klobas, "A tasktechnology fit view of learning management system impact", Computers \& Education, Vol. 52, No. 2, pp. 496-508, 2009.

[60] B. Wu and X. Chen, "Continuance intention to use MOOCs: Integrating the technology acceptance model (TAM) and task technology fit (TTF) model", Computers in Human Behavior, Vol. 67, pp. 221-232, 2017.

[61] S. Afshan and A. Sharif, "Acceptance of mobile banking framework in Pakistan", Telematics and Informatics, Vol. 33, No. 2, pp. 370-387, 2016.

[62] U. Sekaran and R. Bougie, Research methods for business: A skill building approach. John Wiley \& Sons, 2016.

[63] R. V. Krejcie and D. W. Morgan, "Determining sample size for research activities", Educational and psychological measurement, Vol. 30, No. 3, pp. 607-610, 1970.

[64] W. S. Ringle Christian M, Becker Jan-Michael. SmartPLS $3 . \quad$ Available: http://www.smartpls.com.

[65] J. F. Hair Jr, G. T. M. Hult, C. Ringle, and M. Sarstedt, A primer on partial least squares structural equation modeling (PLS-SEM). Sage publications, 2016.

[66] W. W. Chin, "The partial least squares approach to structural equation modeling", Modern methods for business research, Vol. 295, No. 2, pp. 295-336, 1998.

[67] J. F. Hair Jr, L. M. Matthews, R. L. Matthews, and M. Sarstedt, "PLS-SEM or CB-SEM: updated guidelines on which method to use", International Journal of Multivariate Data Analysis, Vol. 1, No. 2, pp. 107-123, 2017.

[68] J. Henseler, C. M. Ringle, and M. Sarstedt, "A new criterion for assessing discriminant validity in variance-based structural equation modeling", Journal of the academy of marketing science, Vol. 43, No. 1, pp. 115-135, 2015.

[69] J. P. Shaffer, "Multiple hypothesis testing," Annual Review of Psychology, Vol. 46, No. 1, pp. 561-584, 1995. 